\title{
IMPLEMENTASI METODE CERTAINTY FACTORY PADA PERANCANGAN SISTEM PAKAR DIAGNOSA KANDUNG KEMIH
}

\author{
Herlan Sutisna[1]; Reza Fattahurrijal[2]; Tuti Alawiyah[3]; Ai Ilah Warnilah[4]
}

Program Studi Sistem Informasi [1][2][3]

Universitas Bina Sarana Informatika Kampus Kota Tasikmalaya

herlan.her@bsi.ac.id[1]; reza.fah@gmail.com[2]; tuti.tah@bsi.ac.id[3]; ai.aiw@bsi.ac.id[4]

\begin{tabular}{ll}
\hline INFO ARTIKEL & INTISARI \\
\hline Diajukan : & Kandung kemih merupakan sebuah organ yang berongga di abdomen \\
b2 Juli 2021 & bagian dasar, bagian tersebut berfungsi menyimpancairan urin dan cairan \\
Diterima : & salah satu bagian dari saluran kecing. Cairan urin yang melalui dari tiap \\
19 Juli 2021 & ginjal mengarah ke kandung kemih lewat selang panjang yang biasa \\
Diterbitkan: & dinamakan dengan ureter. Penyakit kandung kemih ini dapat diderita oleh \\
1 Desember 2021 & anak-anak sampai dengan lansia, mulai dari kandung kemih ringan sampai \\
& kandung kemih kronik, untuk kasus penyakit kandung kemih \\
Kata Kunci : & ringan,kandung kemih akan membaik dengan sendirinya, namun sebagian \\
Data Mining, FP-Growth, & Market \\
Basket Analysis & permasalahan kerap berulang sehingga memerlukan penyembuhan jangka \\
& panjang. Kandung kemih pula bisa menimbulkan komplikasi yang serius \\
& seperti terjadinya peradangan ginjal. Penyakit kandung kemih pula ialah \\
& permasalahan kesehatan yang serius, sebab bisa menyerang berjuta- juta \\
& orang setiap tahunnya dan hal tersebut ialah penyakit yang menempati \\
& sepuluh besar penyakit di salah satu rumah sakit.. Metode yang bisa \\
& digunakan untuk membuktikan apakah sesuatu fakta ataupun tidak pasti \\
& mendiagnosa penyakit kandung kemih yaitu certainty factory(CF). Tujuan \\
dari riset ini adalah memudahkan bagi masyarakat untuk memperoleh & suatu informasi tentang penyakit kandung kemih melalui suatu aplikasi \\
& android. Hasil dari riset ini bisa berguna untuk masyarakat serta bisa \\
digunakan sebagai referensi dasar untuk mengambil solusi dan sistem & pakar yang dapat memudahkan proses diagnosa.
\end{tabular}

\section{PENDAHULUAN}

"Kandung kemih adalah organ berongga di abdomen bagian bawah. Kandung kemih menyimpan urin; cairan limbah yang dihasilkan oleh ginjal. Kandung kemih adalah bagian dari saluran kencing. Urin lewat dari setiap ginjal menuju ke kandung kemih melalui selang panjang yang disebut ureter." (Saputra, 2017).

Penyakit kandung kemih juga merupakan masalah kesehatan yang serius karena dapat menyerang berjuta-juta orang tiap tahunnya. Jumlah pasien kandung kemih mencapai 150 juta per tahun, dan di Amerika dilaporkan 6 juta pasien datang ke dokter dengan diagnosis kandung kemih. Kandung kemih merupakan infeksi nosokomial tersering yang mencapai kira-kira 4060\% (Naber \& Carson) dalam (Suhardin, 2017). Dan merupakan penyakit infeksi saluran kemih yang menempati urutan kedua dan termasuk sepuluh besar penyakit infeksi saluran kemih di salah satu rumah sakit di Yogyakarta (Aris et al) dalam (Suhardin, 2017).
Penyakit kandung kemih ini dapat diderita oleh anak-anak sampai dengan lansia. Dari kandung kemih ringan sampai dengan kandung kemih kronik. Dalam sebuah kasus infeksi yang ringan, dengan sendirinya kandung kemih akan membaik dalam beberapa hari. Tetapi, pada sebagian kasus, kerap berulang sehingga memerlukan penyembuhan atau pengobatan jangka panjang. Kandung kemih pula bisa menimbulkan komplikasi yang yang serisu seperti infeksi pada ginjal.

Penyembuhan penyakit kandung kemih biasanya dengan pengobatan yang dilakukan dokter melalui pemberian antibiotik dengan dosis yang disesuaikan dengan bakteri yang terdapat dalam urin dan tingkat keparahan Kandung Kemih.

Jika tidak diobati secara cepat, kandung kemih dapat menimbulkan komplikasi yang dapat mengancam keselamatan jiwa pasien, seperti kerusakan ginjal, darah dalam urin, dll. Sehingga salah satu kunci agar pasien dapat sembuh adalah deteksi dini dan juga penanganan yang cepat dan 
tepat di awal. Namun dikarenakan minimnya pengetahuan masyarakat mengenai penyakit kandung kemih, baik pengetahuan tentang gejala maupun bahayanya. Sehingga pada saat mengalami gejala-gejalanya masyarakat cenderung mengabaikannya.

Melihat permasalahan tersebut, maka diperlukan suatu sarana atau media yang bisa membantu masyarakat untuk mengetahui informasi tentang penyakit kandung kemih dan mendiagnosa penyakit kandung kemih secara dini, agar penderita dapat langsung ditangani secara cepat dan tepat, juga dapat mengurangi resiko yang lebih parah. Maka penulis tertarik untuk melakukan penelitian mengenai penyakit kandung kemih ini disalah satu Puskesmas yang berada di Kota Tasikmalaya, yaitu tepatnya di UPTD Puskesmas Purbaratu. Dengan melakukan wawancara terhadap Dr. Eddi Sadaryun yang merupakan dokter umum di Puskesmas tersebut. Dimana hasil dari wawancara akan dijadikan sebagai data dan inputan untuk membuat sistem pakar yang dapat mendiagnosa penyakit kandung kemih dengan menggunakan metode certainty factor.

\section{BAHAN DAN METODE}

\section{Teknik Pengumpulan Data}

Sebelum dibuatkan sebuah peracangan dan membangun sistem pakar ini perlu dilakukan sebuah penelitian dan juga memerlukan pengumpulan data. Metode pengumpulan data dilakukan penulis dalam memperoleh informasi dan data ditempuh dengan berbagai cara seperti berikut:

1. Pengamatan/Observasi

Dalam sebuah penelitian, diperlukan sebuah observasi dengan tujuan untuk mempelajari permasalahan apa saja yang sering terjadi proses diagnosa penyakit kandung kemih

2. Wawancara

Metode wawancara dilakukan pada dokter umum di Puskesmas Purbaratu Kota Tasikmalaya. Wawancara dilakukan dengan bahasan mengenai gejala-gejala dari penyakit yang terkait dengan penelitian ini, hal ini bertujuan untuk memperoleh informasi tentang diagnosa penyakit kandung kemih. Berdasarkan hasil wawancara tersebut diperoleh data, yang kemudian akan digunakan dalam pembuatan sistem pakar diagnosa penyakit kandung kemih dengan menggunakan metode certainty factor.

\section{Studi Pustaka}

Untuk memperkuat landasan teori, penulis mencari sumber-sumber lain yang dibutuhkan dalam penelitian ini diantaranya penulis mengunjungi situs-situs yang terdapat di internet dan membaca serta mempelajari dari buku-buku di perpustakaan.

\section{Metode Pengolahan Data}

Penelitian ini menggunakan metode Centrainty Factory, Menurut McAllister dalam (Septiana, 2016) " Certainty Factor adalah suatu metode untuk membuktikan apakah suatu fakta itu pasti ataukah tidak pasti yang berbentuk metric yang biasanya digunakan dalam sistem pakar. Metode ini sangat cocok untuk sistem pakar yang mendiagnosis sesuatu yang belum pasti".

Faktor kepastian (certainty factor) diperkenalkan oleh Shortliffe Buchanan dalam pembuatan MYCIN. Certainty Factor (CF) merupakan nilai parameter klinis yang diberikan MYCIN untuk menunjukkan besarnya kepercayaan.

$\mathrm{CF}(\mathrm{H}, \mathrm{E})=\mathrm{MB}(\mathrm{H}, \mathrm{E})-\mathrm{MD}(\mathrm{H}, \mathrm{E})$

$\mathrm{CF}(\mathrm{H}, \mathrm{E})$ : Certainty Factor dari hipotesis $\mathrm{H}$ yang dipengaruhi oleh gejala (evidence) E.

Besarnya CF berkisar antara -1 sampai 1 . Nilai -1 menunjukkan ketidakpercayaan mutlak sedangkan nilai 1 menunjukkan kepercayaan mutlak.

a. $\mathrm{MB}(\mathrm{H}, \mathrm{E})$ : ukuran kenaikan kepercayaan (measure of increased belief) terhadap hipotesis $\mathrm{H}$ yang dipengaruhi oleh gejala $\mathrm{E}$.

b. MD (H, E) : ukuran kenaikan ketidakpercayaan (measure of increased disbelief) terhadap hipotesis $\mathrm{H}$ yang dipengaruhi oleh gejala $\mathrm{E}$.

c. MB (H, E) : ukuran kenaikan kepercayaan (measure of increased belief) terhadap hipotesis $\mathrm{H}$ yang dipengaruhi oleh gejala $\mathrm{E}$.

d. $\mathrm{MD}(\mathrm{H}, \mathrm{E})$ : (measure of increased disbelief) ukuran peningkatan ketidakpercayaan terhadap hipotesis $\mathrm{H}$ yang dipengaruhi oleh indikasi E.

e. Bentuk dasar rumus certainty factor, merupakan suatu ketentuan JIKA E MAKA H seperti yang tertera pada persamaan 2 berikut:

f. $\quad C F(H, e)=C F(E, e) * C F(H, E)$

g. Dimana:

h. $\mathrm{CF}(\mathrm{H}, \mathrm{e})$ : certainty factor hipotesis yang dipengaruhi oleh evidence e.

i. $\mathrm{CF}(\mathrm{E}, \mathrm{e})$ : certainty factor evidence $\mathrm{E}$ yang dipengaruhi oleh evidence e.

j. $\quad \mathrm{CF}(\mathrm{H}, \mathrm{E})$ : certainty factor hipotesis dengan asumsi evidence diketahui dengan tentu, ialah ketika $\mathrm{CF}(\mathrm{E}, \mathrm{e})=1$ jika seluruh evidence pada antecedent diketahui dengan pasti maka persamaannya akan menjadi:

k. $\mathrm{CF}(\mathrm{E}, \mathrm{e})=\mathrm{CF}(\mathrm{H}, \mathrm{E})$

Dalam aplikasinya, $\mathrm{CF}(\mathrm{H}, \mathrm{E})$ adalah sebuah nilai kepastian yang diberikan oleh pakar terhadap suatu aturan, sebaliknya $\mathrm{CF}(\mathrm{E}, \mathrm{e})$ adalah nilai 
kerpercayaan yang diberikan oleh pengguna terhadap gejala yang dialaminya.

Penelitian ini termasuk merupakan rancangan sistem pakar, dimana sistem pakar menkonversi pengetahuan manusia kedalam komputer, Menurut Kusumadewi dalam (Halim \& Hansun, 2015) "sistem pakar atau expert system adalah sistem yang mengambil pengetahuan manusia dan memanfaatkannya ke komputer, supaya komputer dapat menyelesaikan masalah layaknya manusia atau yang dilakukan oleh pakar pada umumnya, sehingga sistem pakar dapat menyelesaikan suatu masalah, bahkan meniru kerja dari pakar.

\section{HASIL DAN PEMBAHASAN}

Asuhan keperawatan secara nyata berbentuk serangkaian aktivitas yang sistematis bersumber pada perencanaan untuk menggapai hasil yang maksimal disebut sebagai implementasi. seorang perawat hendaklah menjelaskan tindakan keperawatan yang akan dilakukan kepada pasien sebelum melakukan rencana tindakan keperawatan. Dalam penerapannya, seorang perawat melaksanakan fungsinya sebagai independent, interdependent, serta dependent. Pada fungsi dependent seorang perawat melaksanakan tindakannya atas dasar inisiatif sendiri. Contohnya memberikan latihan pernafasan perut dalam posisi duduk dan tiduran, pada fungsi interdependent seorang perawat melaksanakan fungsi kolaborasi dengan tim kesehatan yang lain.dan fungsi independent seorang perawat melaksanakan fungsi tambahan untuk menjalankan program dari tim kesehatan lain seperti penyembuhan. Disamping itu, ha yang harus dilakukan seorang perawat yaitu memperhatikan kesehatan umum dan respon pasien selama masa pengobatan, dan untuk melatih pasien supaya bisa mandiri, maka sebaiknya dalam tahap pelaksanaan pengobatan tersebut meliputi beberapa tahapan yaitu persiapan, pelaksanaan dan dokumentasi.

\section{Kebutuhan Pengguna}

\section{a. Tahapan Perancangan Sistem}

Dalam sistem usulan berbasis mobile dan website ini terdapat dua pengguna, diantaranya user dan admin, dari setiap pengguna memiliki kebutuhan informasi yang berbeda-beda, diantaranya:

1) Skenario Kebutuhan Admin

a. Mengelola data pertanyaan seputar gejala

b. Melihat data user

c. Mencetak data laporan

2) Skenario Kebutuhan User

a. Melihat data informasi mengenai penyakit kandung kemih b. Konsultasi (menjawab pertanyaan seputar gejala penyakit kandung kemih)

c. Melihat hasil diagnosa

d. Melihat statistik persentase diagnosa setiap melakukan konsultasi

3) Kebutuhan Sistem

a. Sistem yang dirancang mempunyai 2 hak akses untuk login yaitu hak aksen untuk user dan hak akses untuk admin.

b. Sistem yang dirancang dapat memproses jawaban pengguna dengan aturan-aturan yang telah ditetapkan

c. Sistem dapat memberikan hasil diagnosa berupa jenis penyakit kandung kemih yang diderita user beserta presentase keyakinannya.

d. Sistem yang diracang dapat memperlihatkan statistik diagnosa pasien.

2. Rancangan Diagram Use Case

1) Rancangan Use Case Diagram Menu Diagnosa Admin

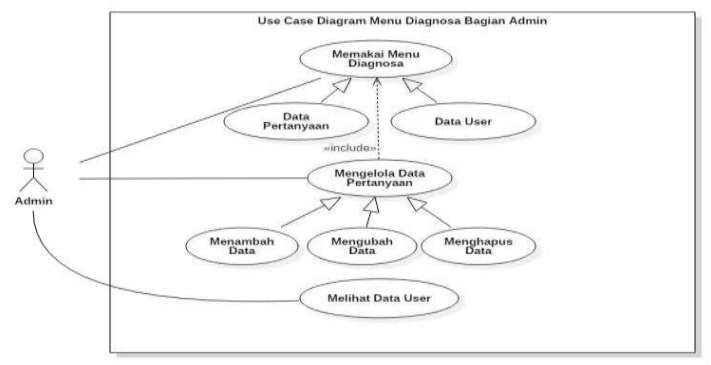

Gambar 1. Rancangan Use Case Diagram Menu Diagnosa Admin

Tabel 1. Deskripsi Rancangan Use Case Diagram Menu Diagnosa Admin

2) Rancangan Use Case Diagram Menu Diagnosa User

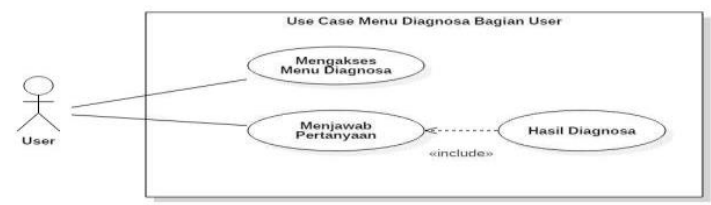

Gambar 2. Rancangan Use Case Diagram Diagnosa User

Tabel 2. Deksripsi Use Case Diagram Diagnosa

\begin{tabular}{|l|l|}
\multicolumn{2}{|c|}{ User } \\
\hline Use Case Name & \multicolumn{1}{c|}{ Diagnosa User } \\
\hline Requirements & $\begin{array}{l}\text { Untuk mendapatkan } \\
\text { hasil diagnosa }\end{array}$ \\
\hline Pre-Conditions & $\begin{array}{l}\text { User berhasil mendapat } \\
\text { hasil diagnosa }\end{array}$ \\
\hline & $1 . \quad$ User memilih \\
\hline
\end{tabular}




\begin{tabular}{|c|c|}
\hline Use Case Name & Diagnosa User \\
\hline & $\begin{array}{l}\text { menu diagnosa } \\
2 . \quad \text { User menjawab } \\
\text { pertanyaan }\end{array}$ \\
\hline Post-Conditions & $\begin{array}{l}\text { System menampilkan } \\
\text { hasil diagnosa }\end{array}$ \\
\hline Failed End Condition & $\begin{array}{l}\text { 1. Usertidak } \\
\text { memilih menu diagnosa } \\
2 . \quad \text { Usertidak } \\
\text { mendapat hasil } \\
\text { diagnosa }\end{array}$ \\
\hline Actors & User \\
\hline Main Flow/Basic path & $\begin{array}{lr}\text { User } & \text { menjawab } \\
\text { pertanyaan } & \text { sebelum } \\
\text { mendapathasil diagnosa }\end{array}$ \\
\hline $\begin{array}{l}\text { Alternate } \\
\text { Flow/Invariant } A\end{array}$ & $\begin{array}{l}\text { A1. User dapat memilih } \\
\text { menu diagnosa yang } \\
\text { tersedia } \\
\text { A2. Sistem secara } \\
\text { otomatis menampilkan } \\
\text { daftar pertanyaan }\end{array}$ \\
\hline Invarian $B$ & $\begin{array}{l}\text { B1. User dapat memilih } \\
\text { menu diagnosa yang } \\
\text { tersedia } \\
\text { B2. User menjawab } \\
\text { daftar pertanyaan } \\
\text { B3. User mendapat hasil } \\
\text { diagnosa }\end{array}$ \\
\hline
\end{tabular}

\section{Rancangan Aktivitas}

1) Rancangan Aktivitas Menu Diagnosa Bagian Admin

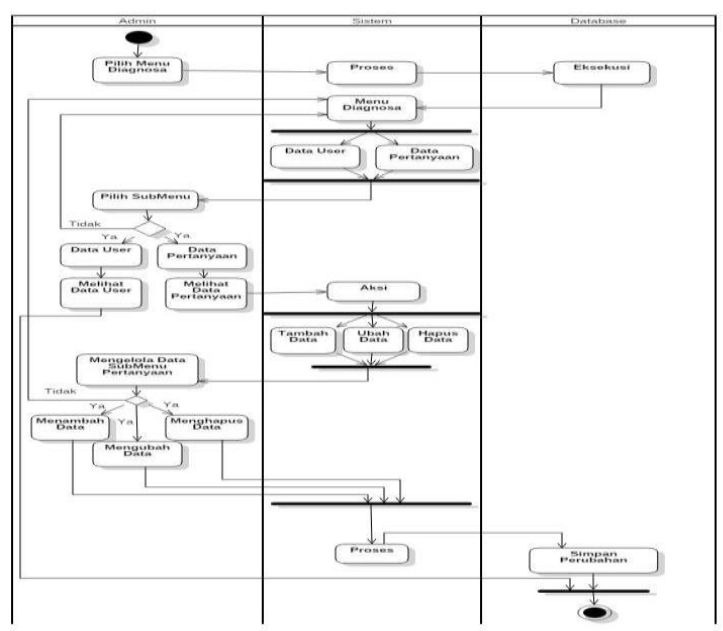

Gambar 3. Rancangan Aktivitas Menu Diagnosa Bagian Admin

2) Rancangan AktivitasMenu Diagnosa User

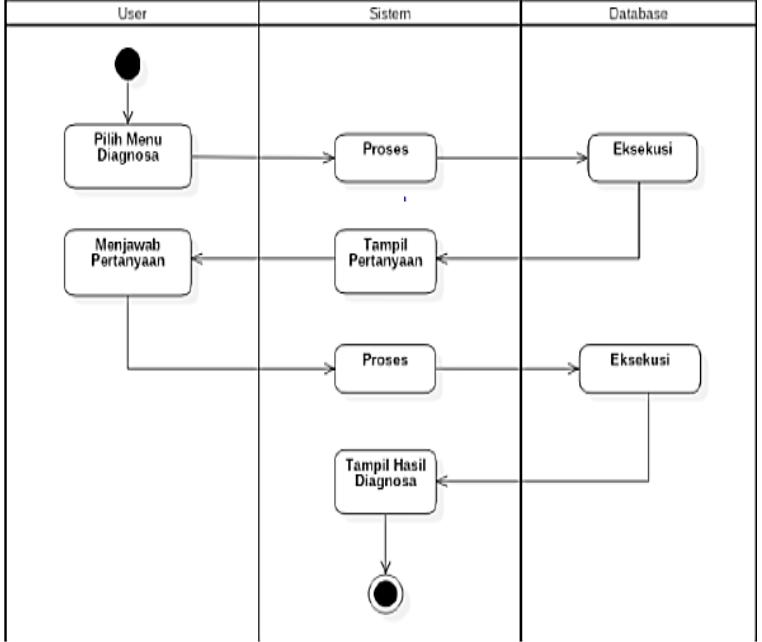

Gambar 4. Rancangan Aktivitas Diagnosa User

\section{Prose Perhitungan Secara Manual dengan Metode Certainty Factor}

Pada pembuatan sistem pakar diagnosa penyakit kandung kemih ini, penulis menggunakan penghitungan certainty factor evidence tunggal yaitu:

\section{CF $(1,2)=$ CF1 + [CF2* $(1-$ CF1)]}

Nilai CF dari setiap gejala yang terdapat pada sistem pakar ini diambil dari orang yang berkompeten dibidangnya atau bisa disebut seorang pakar.

Berikut ini merupakan nilai MB, MD, dan CF pakar dari gejala-gejala penyakit kandung kemih.

Keterangan:

MB : Measures of belief (ukuran kepercayaan)

MD : Measure of belief (ukuran ketidak percayaan) Tabel 3. Data Penyakit Kandung Kemih

\begin{tabular}{|c|l|l|l|c|}
\hline No & \multicolumn{1}{|c|}{ Gejala } & MB & MD & CF \\
\hline 1 & $\begin{array}{l}\text { Terasa sakit saat buang air } \\
\text { kecil }\end{array}$ & 0,6 & 0 & 0,6 \\
\hline 2 & $\begin{array}{l}\text { Frekuensi buang air kecil } \\
\text { meningkat dan sedikit- } \\
\text { sedikit }\end{array}$ & 0,8 & 0,2 & 0,6 \\
\hline 3 & $\begin{array}{l}\text { Sulit menahan buang air } \\
\text { kecil }\end{array}$ & 0,6 & 0 & 0,6 \\
\hline 4 & Selalu ingin buang air besar & 0,6 & 0,2 & 0,4 \\
\hline 5 & Urin keruh & 1 & 0 & 0,4 \\
\hline 6 & Terdapat darah dalam urin & 1 & 0 & 0,4 \\
\hline 7 & Buang air kecil terasa perih & 0,6 & 0 & 0,6 \\
\hline 8 & $\begin{array}{l}\text { Terasa nyeri apabila ditekan } \\
\text { di bagian pubis } \\
\text { (diataskemaluan) }\end{array}$ & 0,6 & 0 & 0,4 \\
\hline 9 & $\begin{array}{l}\text { Terasa nyeri pada perut } \\
\text { bagian bawah }\end{array}$ & 1 & 0 & 0,6 \\
\hline 10 & $\begin{array}{l}\text { Terasa sakit di bagian vagina } \\
\text { / area belakang vagina }\end{array}$ & 0,8 & 0 & 0,8 \\
\hline 11 & $\begin{array}{l}\text { Terasa sakit pada kantung } \\
\text { zakar, testis, penis, danarea } \\
\text { belakang kantung zakar }\end{array}$ & 0,8 & 0 & 0,8 \\
\hline 12 & $\begin{array}{l}\text { Terasa sakit pada punggung } \\
\text { bawah, pinggang ataupangkal } \\
\text { paha }\end{array}$ & 0,6 & 0 & 0,8 \\
\hline
\end{tabular}




\begin{tabular}{|c|c|c|c|c|}
\hline 13 & Mual dan Muntah & 1 & 0 & 0,4 \\
\hline 14 & Merasa ingin buang air kecil & 0,8 & 0 & 0,6 \\
\hline 15 & $\begin{array}{l}\text { Terasa panas saat buang air } \\
\text { kecil }\end{array}$ & 0,6 & $\mathbf{0}$ & 0,8 \\
\hline 16 & Nyeri saat ejakulasi & 0,8 & 0 & 0,6 \\
\hline 17 & Badan terasa lemas & 0,4 & 0 & 0,4 \\
\hline 18 & $\begin{array}{l}\text { Demam (suhu diatas } 38,5 \\
\text { derajat celcius) }\end{array}$ & 0,6 & 0 & 0,4 \\
\hline 19 & Rasa dingin dan menggigil & 0,6 & 0 & 0,6 \\
\hline 20 & Beser (Inkontenensia Urine) & 0.8 & 0 & 0,4 \\
\hline 21 & $\begin{array}{l}\text { Terasa sakit pada punggung } \\
\text { bawah, pinggang ataupangkal } \\
\text { paha }\end{array}$ & 0,8 & 0 & 0.8 \\
\hline
\end{tabular}

Dan berikut pada tabel dibawah ini merupakan Jenis penyakit kandung kemih:

Tabel 4. Jenis Penyakit Kandung Kemih

\begin{tabular}{|c|l|}
\hline No. & \multicolumn{1}{|c|}{ Jenis Penyakit kandung kemih } \\
\hline 1 & ISK ( Infeksi Saluran Kemih) \\
\hline 2 & Batu Ginjal \\
\hline 3 & Batu Ureter \\
\hline 4 & $\begin{array}{l}\text { Bening Prostate Hyperplasia (Pembesaaran Prosta } \\
\text { Jinak) }\end{array}$ \\
\hline 5 & Prostatitis ( Peradangan / Pembekakan) \\
\hline
\end{tabular}

Berikut ini, logika metode certainty factor pada sesi diagnosa sistem.

Tabel 5. Nilai Bobot User

\begin{tabular}{|c|c|c|}
\hline Kondisi & Ya & Tidak \\
\hline Bobot & 1 & 0 \\
\hline
\end{tabular}

Tabel 6. Nilai Bobot Pakar

\begin{tabular}{|c|c|c|c|c|c|c|}
\hline Kondisi & Tidak & Ragu & Sedikit & Cukup & Yakin & Sangat \\
\hline Bobot & Yakin & & Yakin & Yakin & & Yakin \\
\hline & 0 & 0,2 & 0,4 & 0,6 & 0,8 & 1 \\
\hline
\end{tabular}

Misal penyakit Batu Kandung Kemih/Batu Ginjal

\section{Rule 1:}

IF Terasa Mual dan Muntah AND Terasa nyeri perut bagian bawah AND Sulit menahan buang air kecil AND Urin keruhAND THEN = Batu Ginjal.

langkah awal yang dilakukan dalam menentukan CF Pakar pada setiap masing-masing gelaja

CFpakar (Terasa Mual dan Muntah) $=0,6$

CFpakar (Terdapat darah dalam urin) $=0,4$

Cfpakar (Terasa nyeri perut bagian bawah) $=0,6$

CFpakar (Urin keruh) $=0,4$

Contoh rule diatas mempunyai sebanyak 4 premis dan selanjutnya dipecah menjadi premis tunggal sehingga menghasilkan rule sebagai berikut :

\section{Rule 1.1 :}

IF Terasa Mual dan Muntah

THEN Jenis = Batu Ginjal

Rule 1.2 :
IF Darah dalam Urin

THEN Jenis = Batu Ginjal

\section{Rule 1.3 :}

IF Terasa nyeri perut bagian bawah

THEN Jenis = Batu Ginjal

\section{Rule 1.4 :}

IF Urin keruh

THEN Jenis = Batu Ginjal

kemudian dilakukan proses perhitungan dengan mengkombinasikan CF1 dengan CF2 dengan menggunakan rumus:

\section{$\mathrm{CF}(1,2)=\mathrm{CF} 1+[\mathrm{CF} 2 *(1-\mathrm{CF} 1)]$}

CFcombine $(\mathrm{CF} 1 . \mathrm{CF} 2)=0.6+[0.4 *(1-0.6)]$

$$
=0.6+0.16
$$$$
=0.76=\text { CFold }
$$

CFcombine(Cfold, CF3) $=0.76+[0.6 *(1-0.76)]$

$$
\begin{aligned}
& =0.76+0.114 \\
& =0.904=\text { CFold }
\end{aligned}
$$

CFcombine(Cfold, CF4) $=0.904+[0.4 *(1-0.904)]$

$$
=0.904+0.0384
$$$$
=0.9424=\text { Cfold }
$$

Jadi Presentasi keyakinan

CFcombine $=0.9424 * 100 \%$

Sehingga kemungkinan user terserang penyakit Batu Ginjal

adalah 0.9424atau 94.24\%.

\section{Pembuatan Rancangan Prototype}

Pembuatan perancangan prototype dimaksudkan untuk penggambaran interface dari sistem pakar yang akan dibuat, diantaranya:

a) Interface Tampilan Splash Aplikasi Android Sistem Pakar

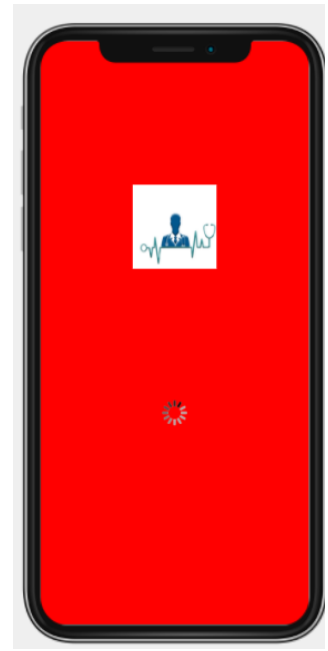

Gambar 5. Interface Tampilan Splash Aplikasi Android Sistem

3) Interface Menu Utama User 


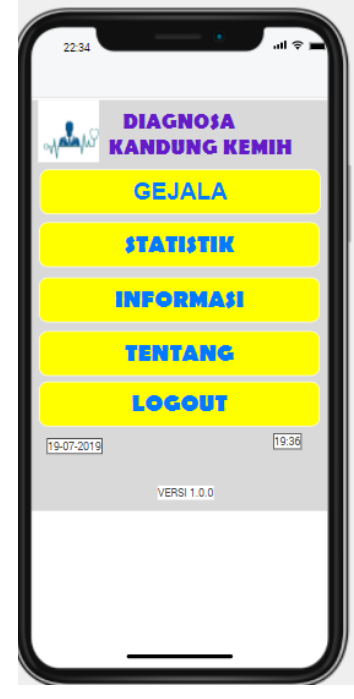

Gambar 6. Tampilan Menu Utama Untuk User 4) Interface Menu Diagnosa User

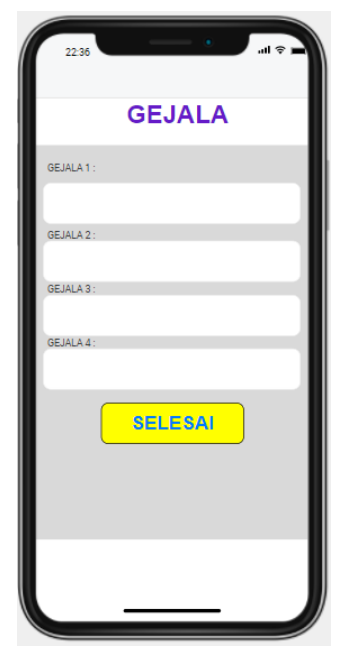

Gambar 7. Tampilan Menu Diagnosa untuk User

5) Interface Hasil Diagnosa

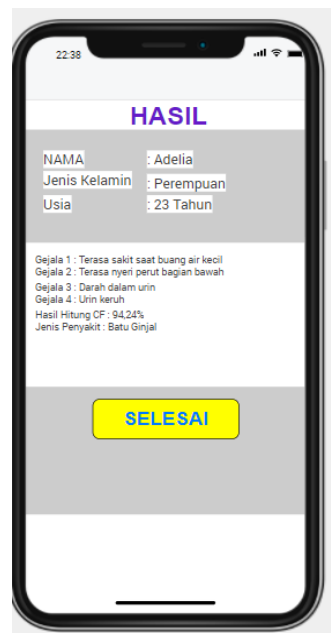

Gambar 8. Interface Hasil Diagnosa

6) Interface Menu Statistik

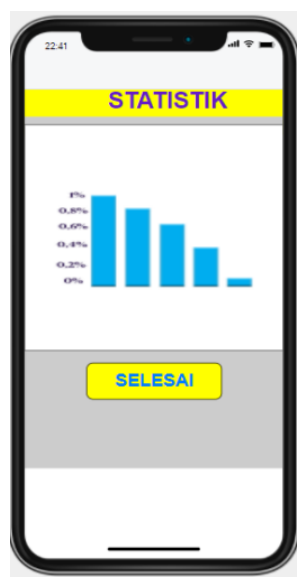

Gambar 9. Menu Statistika

\section{Perancangan Perangkat Lunak}

Pada tahap Perancangan Perangkat Lunak ini dijelaskan mengenai Rancangan Basis Data dan Rancangan Antarmuka sistem usulan dari Sistem Pakar Diagnosa Penyakit kandung kemih. Entity Relationship Diagram (ERD)

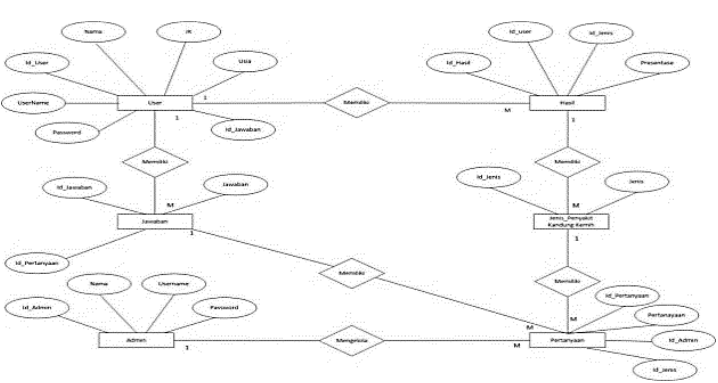

Gambar 10 pembuatan ERD

Logical Record Structure (LRS)
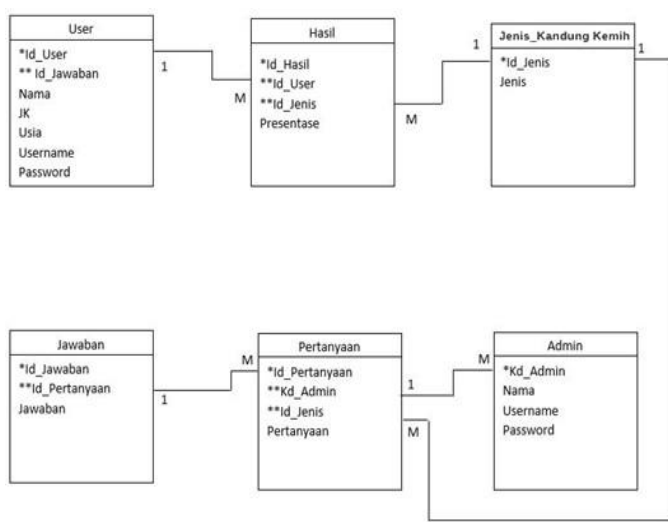

Gambar 11. Pembuatan (LRS) 


\section{Class Diagram}

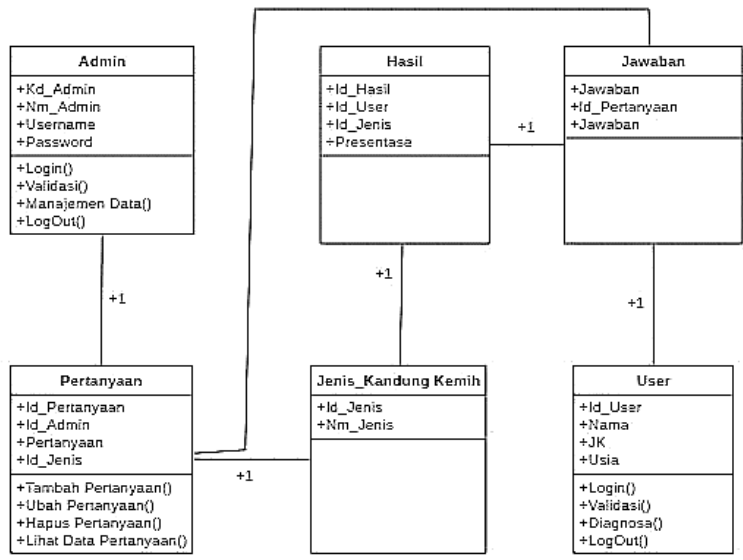

Gambar 12. pembuatan digram kelas

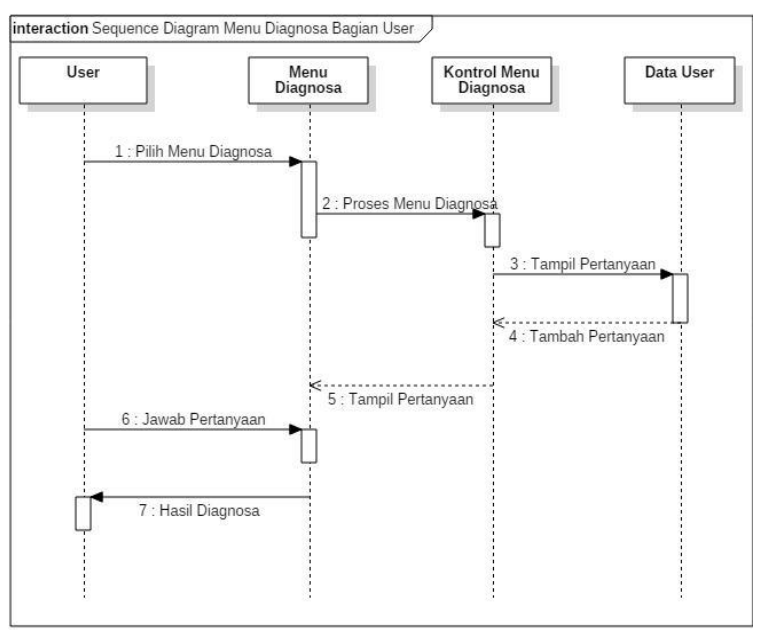

Gambar 13. Sequence Diagram Menu Diagnosa Bagian User

\section{KESIMPULAN}

Penyakit Kandung Kemih umum nya di derita oleh anak-anak sampai lansia dan kebanyaka menyerang perempuan di bandingkan dengan laki-laki. Dengan dibuatnya rancangan sistem pakar diagnosa penyakit kandung kemih ini diharapkan dapat menambah ilmu pengetahuan tentang penyakit kandung kemih dan pengetahuan tentang penerapan metode certainty factor pada sebuah sistem pakar yang dapat mempermudah proses diagnosa. Diharapkan sistem usulan ini bisa memberikan manfaat yang sebesar-besarnya dan memberikan manfaat yang lebih baik, serta bisa menjadi referensi dasar untuk mengambil solusi dari permasalahan yang ada.

\section{REFERENSI}

Saputra, K. (2017). Akupunktur Dasar: Edisi 2.

Burhan, N. (2018). Sistem Informasi Penjualan dan Persediaan Barang Dagang Pada Perusahaan Hakasima Kota ternate, 1(1), 39-49.

Hutahaean, J. (2015). Konsep Sistem Informasi.

Sianipar, R. H. (2013). Teori Dan Implementasi Pemrograman Berorientasi Objek Menggunakan $\mathrm{C}++$.

Febriadi, B. (2015). Bimbingan Penasehat Akademik Menggunakan, 59-65.

Fridayanthie, E. W., \& Mahdiati, T. (2016). Rancang Bangun Sistem Informasi Permintaan Atk Berbasis Intranet (Studi Kasus: Kejaksaan Negeri Rangkasbitung). Jurnal Informatika, 4(2), 126- 137.

Halim, S., \& Hansun, S. (2015). Penerapan Metode Certainty Factor dalam Sistem Pakar Pendeteksi Resiko Osteoporosis dan Osteoarthritis. ULTIMA Computing, VII(2), 59-69.

Musa, M., \& Nurfitri, T. (1998). Metode Penelitian, 123.

Susanti. (2015). Sistem Informasi Manajemen ( SIM ) Pembelian dan Penjualan pada Apotek Mahkota. 